\title{
Correlation Between Long Hemodialysis And Nutritional Status Of Chronic Renal Failure In Hemodialysis Unit At Rsud Ulin Banjarmasin
}

Putri Vidiasari D*, Bagus Rahmat S, Rizka Fitriana

STIKES Sari Mulia Banjarmasin

putri_vidiasari@stikessarimulia.ac.id

Bagus Rahmat $\mathrm{S}$

STIKES Sari Mulia Banjarmasin

bagus_rahmat_santoso@stikessarimulia.ac.id

Rizka Fitriana

STIKES Sari Mulia Banjarmasin

Rizka_fitriana@gmail.com

\begin{abstract}
Objective: In order to know the correlation between long hemodialysis and nutritional status of chronic renal failure at hemodialysis unit of Ulin Hospital Banjarmasin.

Technology or Method: This research was an analytic survey research with Cross-Sectional approach. The sampling technique used Purposive Sampling with the number of samples was 182 . The data collection was by using checklists and questionnaires. The research used statistical analysis of Chi-Square test.

Results: Clients of chronic renal failure kindy with long hemodialysis $>1$ year were 120 people (65, $9 \%)$ and hemodialysis $<1$ year werec62 people and non-malnutrition were 100 people $(54,9 \%)$ and experienced Malnutrition were 82 people $(42,1 \%)$. Non- malnourished hemodialysis clients $<1$ year were 28 people $(45.2 \%)$ and with malnourished 34 people (54.8\%). Non- malnourished Hemodialysis clients $>1$ year were 72 people $(60 \%)$ and with malnourished 48 people $(40 \%)$.

Conclusion: There was no significant correlation between long hemodialysis and nutritional status in chronic renal failure clients. With value of P-value amount

$0,057 \geq 0,05$.
\end{abstract}

Keywords: chronic renal failure, hemodialysis, malnutrition, nutritional status.

\section{INTRODUCTION}

Kidney failure occurs when the kidney is unable to transport the body's metabolic waste or perform its regular function. A substance usually in urine elimination accumulates in body fluids due to renal secretion disorder resulting in impaired endocrine and metabolic functions, fluids, electrolytes and acid-base [1].

In chronic renal failure is usually the result of terminal tissue destruction and loss of kidney function that gradually emerged. This condition can also occur due to rapidly progressive disease and can destroy the nephron and cause irreversible kidney 
damage. Some new symptoms occur after the remaining glomerular filtration function is less than $25 \%$. This syndrome will lead to death if not properly administered, but dialysis therapy maintains the patient's life [2].

The prevalence of chronic renal failure increases every year. The increasing number of clients with chronic renal failure results in an increase in the number of patients undergoing hemodialysis. At the end of 2004, the incidence of kidney failure worldwide increased to reach $1,371,000$ patients undergoing hemodialysis therapy [3].

Clients with chronic renal failure will experience severe and chronic renal dysfunction resulting in difficult clients to help. One of the proper handlings for chronic renal failure clients is kidney replacement therapy. Therapy is often done is hemodialysis, which is a method by using an artificial kidney machine. The principle of hemodialysis is to clean and regulate plasma levels in the blood which will be replaced by artificial machines. Usually, hemodialysis performed routinely 2-3 times a week for 4-5 hours [4].

If the hemodialysis action itself is done in a long time then the more fluid produced and the drawn fluid gets bigger. Long undergoing hemodialysis undertaken by clients of chronic renal failure is expected to improve the quality of life of clients [5].

Hemodialysis action in chronic renal failure patients has an impact on the decrease of the immune response. Changes in the immune system can cause a decrease in the body's immune system, making it easier for infection [6]. The two conditions that accompany the client with chronic renal failure with hemodialysis are inflammation and malnutrition. Malnutrition is a condition of reduced nutrition in the body because of an imbalance between intake and nutritional needs. It causes symptoms of metabolic disorders, decreased tissue function and loss of body mass. In chronic renal failure clients with hemodialysis often have malnutrition energy proteins (PEM) [7].

Body Mass Index (BMI) is a simple tool or way to monitor the nutritional status of adults, especially those related to deprivation and overweight. Weight loss can increase the risk of infectious diseases, while more weight will increase the risk of degenerative diseases. Therefore, maintaining a normal weight allows one to achieve a longer life expectancy [8]. Many examination methods or parameters to assess nutritional status, but there is no way of assessment that can describe perfectly the nutritional status of hemodialysis clients. Initial assessment of nutritional status should continue to be done dynamically using a fast, accurate, efficient, and easy-to-do method. MalnutritionInflammation Score (MIS) with blood biochemical parameters (serum albumin) as well as the anthropometric examination is a usable method [9]. 
From the preliminary study conducted on 30 December 2016 to 4 January 2017 in hemodialysis unit ULIN Hospital Banjarmasin, obtained data on the number of clients in 2014 clients who underwent hemodialysis of 3.137 while in 2015 amounted to 3,296 and in 2016 amounted to 4038. From IMT measurement results obtained 5 of 7 clients, 5 clients have less weight. Based on this background, it is necessary to research about the duration of hemodialysis on the nutritional status of chronic renal failure patients in hemodialysis unit of ULIN Hospital, Banjarmasin.

\section{METHODS}

The population used was a client of chronic renal failure who underwent hemodialysis in hemodialysis unit of RSUD Ulin Banjarmasin in 2016 which amounted to 337 people and the sample used was 182 people with purposive sampling technique. The research method used analytic survey design with cross-sectional approach. Independent variable of research is long hemodialysis and the dependent variable is nutritional status. Data collection using checklists and questionnaires.

The data analysis method in this research covers the following:

\section{a. Univariate Analysis}

Univariate analysis was performed on each variable from the research result to know the distribution, frequency, and percentage of each variable studied.

\section{b. Bivariate Analysis}

This analysis is conducted on two variables that are suspected to be related (to test the hypothesis) that is to know the relation of the independent variable with dependent variable through Chi-Square Test.

\section{RESULTS}

The respondents' characteristic based on the genders can be seen in the table below:

Tabel 1 Frequency distribution of respondents' genders

\begin{tabular}{lll}
\hline Genders & $\mathrm{f}$ & $\%$ \\
\hline Males & 88 & 48,4 \\
Females & 94 & 51,6 \\
\hline Total & 40 & 100 \\
\hline
\end{tabular}

From table 1 showing the characteristics of respondents by gender, it can be seen that from 182 respondents, female respondents have the largest number of 94 respondents $(51.6 \%)$, while male respondents are 88 respondents $(48.4 \%)$.

The respondents' characteristics based on the age can be seen in table 2 below:

\begin{tabular}{llc}
\multicolumn{4}{l}{ Table 2 Distribution of Respondent's age frequency } \\
\hline Ages (years) & F & $\%$ \\
\hline $23-39$ years & 65 & 35,7 \\
$40-56$ years & 85 & 46,7 \\
$57-72$ years & 32 & 17,6 \\
\hline Total & 182 & 100 \\
\hline
\end{tabular}

Table 2 on the characteristics of respondents by age shows that from 182 respondents, respondents aged 40-56 years had the largest number of 85 people $(46.7 \%)$, while respondents with age 23-39 years were 
65 people $(35.7 \%)$, and respondents aged 5752 years were 32 people $(17.6 \%)$.

Characteristics of respondents based on the frequency of duration of hemodialysis can be seen in the following table:

Table 3 Frequency distribution of the duration of hemodialysis on the respondents

\begin{tabular}{ccc}
\hline Category & F & $\%$ \\
\hline$<1$ year & 62 & 34,1 \\
$>1$ year & 120 & 65,9 \\
\hline Total & 182 & 100 \\
\hline
\end{tabular}

Table 3 explains that of the 182 respondents, the number of respondents who experienced hemodialysis> 1 year had the largest number of 120 people $(65.9 \%)$, while respondents who underwent hemodialysis $<1$ year amounted to 62 people (34.1\%).

Characteristics of respondents based on nutritional status can be seen in the following table:

Table 4 Frequency distribution of Distribusi of the level of nutrition status of the respondents

\begin{tabular}{lll}
\hline \multicolumn{1}{c}{ Nutritional status } & $\mathrm{f}$ & $\%$ \\
\hline $\begin{array}{l}\text { Without Malnutrition } \\
\text { Malnutrition }\end{array}$ & 100 & 54,9 \\
\hline Total & 82 & 42,1 \\
\hline
\end{tabular}

Table 4 shows that of the 182 respondents, the number of respondents without malnutrition has the largest number of 100 people (54.9\%), while the respondents with malnutrition amounted to 82 people $(42.1 \%)$.
Characteristic of the respondents based on the duration of hemodialysis process and nutritional status can be seen in table 5 below:

Table 5 Relationship of the duration of hemodialysis to nutritional status of chronic renal failure patients in Hemodialisa Di unit Ulin Banjarmasin Hospital.

\begin{tabular}{|c|c|c|c|c|c|c|}
\hline \multirow{3}{*}{$\begin{array}{l}\text { Durat } \\
\text { ion } \\
\text { Hemo } \\
\text { dialys } \\
\text { is }\end{array}$} & & & $\begin{array}{c}\text { nutriti } \\
\text { onal } \\
\text { status }\end{array}$ & & & \\
\hline & $\begin{array}{l}\text { Witho } \\
\text { ut Mal } \\
\text { nutriti } \\
\text { on }\end{array}$ & & $\begin{array}{l}\text { Malnu } \\
\text { trition }\end{array}$ & & $\mathrm{f}$ & $\%$ \\
\hline & $\mathrm{f}$ & $\%$ & $\mathrm{f}$ & $\%$ & & \\
\hline $\begin{array}{l}<1 \\
\text { tahun }\end{array}$ & 28 & 45,2 & 34 & $\begin{array}{c}54, \\
8\end{array}$ & 62 & 100 \\
\hline $\begin{array}{l}>1 \\
\text { tahun }\end{array}$ & 72 & 60 & 48 & 40 & $\begin{array}{c}12 \\
0 \\
\end{array}$ & 100 \\
\hline $\mathrm{N}$ & 100 & $\begin{array}{c}57,1 \\
4\end{array}$ & 82 & $\begin{array}{c}45, \\
1\end{array}$ & $\begin{array}{c}18 \\
2 \\
\end{array}$ & 100 \\
\hline
\end{tabular}

Based on table 5 with Chi-Square test

it is found that the duration of hemodialysis on nutritional status is not significant. This can be seen from the insignificant value of $\mathrm{P}$ value of 0.057 . This indicates that the value is greater than the value of $\alpha$ is $\leq 0.05$ where it is $p \geq \alpha$ then the hypothesis is rejected which means there is no influence of the duration of hemodialysis on nutritional status in chronic renal failure patients in hemodialysis unit RSUD Ulin Banjarmasin.

\section{DISCUSSION}

Based on table 1 on the frequency distribution of respondent's gender in line with previous research which stated that from 50 clients, long undergoing hemodialysis in category $<1$ year counted 33 people $(63 \%)$, 
while in category> 1 year as many as 17 people (34\% ) [7].

The duration of hemodialysis is closely related to the efficiency and adherence of hemodialysis so that long hemodialysis is also affected by the level of uremia due to the progression of worsening renal function and its comorbid factors, as well as the velocity of blood flow and flow rate of dialysate [10]. However, the longer the hemodialysis process, the longer the blood is outside the body, the more anticoagulants are needed, with the consequences of frequent side effects [4].

The duration of hemodialysis is defined as how long a person has undergone hemodialysis. The purpose of hemodialysis therapy is not to cure the client of chronic kidney disease because the disease is irreversible. The ultimate goal is to replace the kidneys to maintain the homeostasis of the human body. The longer a client undergoing hemodialysis therapy is inversely proportional to the quality of life of a terminal kidney disease client. This is because the level of anxiety and stress of the client is increasing because thinking should be hemodialysis can cure his client [11].

In clients with chronic renal disease undergoing hemodialysis undergo many physical, psychological, and social changes associated with the disease process and the client's ability to adapt to change. Chronic renal disease with hemodialysis is associated with physical symptoms and complications such as heart disease, anemia, sleeping disorders that can be caused by the duration of dialysis therapy and chronic pain. In addition, cause neurological disorders and gastrointestinal disorders that affect the quality of life of patients. Each physical change has the potential to degrade the quality of life [12]. Hemodialysis therapy takes a long time, costs a lot, and requires client compliance regarding fluid retention and diet. Clients will lose freedom due to various rules, the client relies heavily on the healthcare provider. Income will be reduced or even lost due to unproductive clients. Supported by several other aspects such as physical, psychological, environmental aspects, it can affect the quality of life of renal failure clients [3].

Characteristics of respondents based on the frequency of nutritional status in table 3 show that respondents mostly did not experience malnutrition as many as 100 people or $54.9 \%$ and malnutrition respondents as much as 82 people or $42.1 \%$. This is in line with research that says that of 40 respondents who undergo hemodialysis as many as 36 people $(83.7 \%)$ experienced no malnutrition and as many as 7 people (16.3\%) malnutrition [6].

Clients with chronic renal failure who undergo hemodialysis are at risk of malnutrition. Inadequate Hemodialysis may be an important cause of malnutrition. Malnutrition can increase the risk of morbidity and mortality. Regular nutritional 
status checks on hemodialysis clients are considered important and can detect malnutrition early. Causes of poor nutrition in chronic renal failure patients undergoing hemodialysis are actually very multifactoral, including poor dietary intake, loss of nutrients in dialysis fluids, increased catabolism, chronic inflammation, and catabolic stimuli from the hemodialysis client itself. Factors causing low energy and protein intake in clients of chronic renal failure who undergo hemodialysis are socioeconomic factors (lack of knowledge and poverty). Another factor is the effect of hemodialysis procedures such as inadequate hemodialysis which causes nausea and vomiting and complications of comorbidities. Other factors of diet are inadequate diet and uremia also cause anorexia in clients of chronic renal failure who are hemodialysis [13].

Anorexia is a lack of appetite, the cause of diminished appetite is multifactorial and is associated with central nervous system and Peifer. The etiology of decreased appetite in hemodialysis clients is associated with various factors including uremic toxicity, metabolic acidosis, and increased magnitude of inflammation and oxidative stress [14]. The lack of appetite in chronic renal failure patients undergoing hemodialysis causes PEM (malnutrition energy protein).

From the result of a statistical test using Chi-Square test obtained $\mathrm{P}$ value equal to 0,057 . This indicates that the value is greater than $\alpha$ is $\geq 0.05$ where in this case the hypothesis is rejected which means there is no relationship between the duration of hemodialysis to the nutritional status of chronic renal failure patients at hemodialysis unit of Ulin Hospital Banjarmasin. It is shown in table 4 that underwent hemodialysis <1 year without malnutrition of 28 respondents and malnutrition of 34 people, and who underwent hemodialysis> 1 year without malnutrition of 72 respondents and malnutrition of 48 respondents.

That clients undergoing hemodialysis who have long been able to accept the condition that must undergo lifelong therapy, lose the freedom of various rules, and depend on the health workers. In addition, hemodialysis therapy can follow by the client because it can adapt to tools/units of HD so that the client remains the spirit undergoing hemodialysis.

Progressive chronic kidney disease can change the protein-calorie intake. The process of diffusion in the dialysis procedure is performed by draining the blood into an artificial kidney tube composed of two separate components. Large molecules will be slow compared to small molecules. This process can lead to loss of nutrients to the client so that the longer time hemodialysis then the client's nutrition will be reduced. Ultimately leading to decreased tissue function and loss of body mass [15].

Decreased glomerular filtration rate will decrease protein and energy intake due to increased accumulation of uremic toxin which 
causes dietary changes due to the occurrence of anorexia. The needs and metabolism of some of the body's nutrients change significantly, for example, as a result of restriction of protein intake done to reduce the accumulation of urea derived from protein catabolism. In addition, changes in the metabolism of amino acids formed kidney due to chronic kidney diseases itself such as arginine, serine, and tyrosine. This change causes the patient to have a high risk for the occurrence of protein-calory malnutrition (PEM) or malnutrition [16].

Decreased glomerular filtration rate (<60 Ml/min / $1.73 \mathrm{~m}^{2}$ ) leads to decreased renal clearance (liners) resulting in accumulation of toxic materials (uremia). The incidence of uremia accompanied by increased inflammatory cytokines in the body causes anorexia which affects food intake. Malnutrition and inflammation in patients with chronic renal failure predialysis are used as a predictor of the outcome of both the prognosis of the course of the disease. Possible complications arising, as well as the quality of life of the next client.

Many examination methods or parameters to assess nutritional status, but no single way of assessment that can describe perfectly the nutritional status of hemodialysis clients. Initial assessment of nutritional status should continue to be done dynamically using a fast, accurate, efficient, and easy-to-do method. Malnutrition-inflammation score (MIS) with blood biochemical parameters (serum albumin) and anthropometric examination are the methods that can be used and recommended [9].

\section{CONCLUSION}

There is no correlation between the duration of hemodialysis on nutritional status in chronic renal failure patients in Hemodialisa Unit Ulin Banjarmasin Hospital.

\section{REFERENCES}

[1]. Roesli, R. Hipertensi, diabetes, dan gagal ginjal di Indonesia. Medan: USU Press.pp;95-108. 2008.

[2]. Jenifer P. Kowalak, wiliam welsh, Brenna Mayer."Buku ajar patofisiologi" Ahli bahasa : Andry Hartono, Jakarta:EGC, 2011.

[3]. Nurchayanti S. Analisis faktor-faktor yang berhubungan dengan kualitas hidup pasien penyakit ginjal kronik yang menjalani hemodialisis di RST Fatimah Cilacap dan RSUD Banyumas [Tesis]. Jakarta: Universitas Indonesia. 2011.

[4]. Roesli, Rully M.A. Diagnosis \& Pengelolaan Gangguan Ginjal Akut.Jakarta: Puspa Swara. 2010.

[5]. Suwitra K. Penyakit Ginjal Kronik. Buku Ajar Ilmu Penyakit Dalam (6th ed). Jakarta: Interna Publishing, 2014; p. 2159-65.

[6]. Dian Isti Anggraini. The Different of Protein Intake Between Chronic Renal Failure Patients with Malnutrition and Not Malnutrition in Hemodialysis Unit at dr. Abdul Moeloek Hospital Bandar Lampung. Jurnal Kedokteran \& Kesehatan. 2015.2(2): 163-168.

[7]. Liza Salawati. Analisis Lamanya Hemodialisa Dengan Status Gizi Penderita Ginjal Kronik di RSUD dr. Zainoel Abidin.[Skripsi]. Banda Aceh. Universitas Syiah Kuala. 2012.

[8]. Kumala M, Lukito W, Sastroamijoyo S and Prodjosudjadi W. Fat free mass index as parameter of nutritional status in non 
dialysis CKD patients stage 3, 4 and 5 . Med Journal Indonesian. 2008; (17): 40247.

[9]. Baris Afsar, Siren Sezer, Fatma Nurhan Ozdemir, Huseyin Celik, Rengin Elsurer and Mehmet Haberal. MalnutritionInflammation Score Is A Useful Tool In Peritoneal Dialysis Patients. Peritoneal Dialysis. 2006. vol. 26 no. 6 705-711.

[10]. Qureshi AR, Alvestrand A, Filho JCD, Gutierrez A, Heimburger O, Lindholm B, et al. Inflammation, malnutritional and cardiac disease as predictors of mortality in hemodialysis patient. Journal of The American Society of Nephrologi 13. 2002:S28-S36.

[11]. Anees M, Hammed F, Mumtaz, Ibrahim M, Khan MNS. Dialysis-related factors affecting quality of life in patients on hemodialysis. IJKD.5(1);9-14. 2011.

[12]. Utami OC. Hubungan antara lama hemodialisis dengan kualitas hidup pada pasien gagal ginjal kronik di RSUD Tugurejo Semarang. [Skripsi].
Universitas Muhammadiyah Semarang. 2014.

[13]. Susetyowati. Pengaruh Konseling Gizi dengan Buklet Terhadap Konsumsi Makanan Dan Status Gizi Penderita Ginjal Kronik Dengan Hemodialisis di RS Dr.Sardjito Yogyakarta. Jakarta: Prosiding Kursus Penyegar Ilmu Gizi. 2002.

[14]. Kemenkes RI. Panduan Praktik Klinis Bagi Dokter Di Fasilitas Pelayanan Kesehatan Primer. Jakarta. Direktorat Kementrian Kesehatan RI. 2014.

[15]. Stenvinkel P, Lindholm B, Lonnqvist F, Katzarski K, Heimburger O: Increases in serum leptin during peritoneal dialysis are associated with inflammation and a decrease in lean body mass. J Am Soc Nephrol 2000;11:1303-1309.

[16]. Kalantar Zadeh K, Ikizler TA, Block G, Avram MM, Kopple JD .2003. Malnutrition inflammation complex syndrome in dialysis patients: causes and consequences. Am J Kidney Dis.2003;42 (5) : 864-81 